\title{
Bone char effects on soil: sequential fractionations and XANES spectroscopy
}

\author{
Mohsen Morshedizad ${ }^{1}$, Kerstin Panten ${ }^{2}$, Wantana Klysubun ${ }^{3}$, and Peter Leinweber ${ }^{1}$ \\ ${ }^{1}$ Soil Science, Faculty of Agricultural and Environmental Sciences, University of Rostock, \\ Justus-von-Liebig Weg 6, 18051 Rostock, Germany \\ ${ }^{2}$ Institute for Crop and Soil Science, Julius Kühn Institute, Bundesallee 50, D-38116 Braunschweig, Germany \\ ${ }^{3}$ Synchrotron Light Research Institute, 111 University Avenue, Muang District, \\ Nakhon Ratchasima 30000, Thailand
}

Correspondence: Peter Leinweber (peter.leinweber@uni-rostock.de)

Received: 22 May 2017 - Discussion started: 23 June 2017

Revised: 19 October 2017 - Accepted: 14 November 2017 - Published: 12 January 2018

\begin{abstract}
The acceptability of novel bone char fertilizers depends on their $\mathrm{P}$ release, but reactions at bone char surfaces and impacts on soil P speciation are insufficiently known. By using sequential fractionation and synchrotron-based X-ray absorption near-edge structure (XANES) spectroscopy we investigated whether and how the chemical composition of bone char particles has been altered in soil and has consequently affected the $\mathrm{P}$ speciation of amended soils. Therefore, two different kinds of bone char particles (BC produced by the pyrolysis of degreased animal bone chips at $800^{\circ} \mathrm{C}$ and $\mathrm{BC}$ plus , a $\mathrm{BC}$ enriched with reduced sulfur compounds) were manually separated from the soil at the end of two different experiments: incubation leaching and ryegrass cultivation. Sequential $\mathrm{P}$ fractionation of amended soils showed $\mathrm{P}$ enrichment in all fractions compared to the control. The most $\mathrm{P}$ increase between all treatments significantly occurred in the $\mathrm{NaOH}-\mathrm{P}$ and resin-P fractions in response to $\mathrm{BC}$ plus application in both incubation-leaching and ryegrass cultivation experiments. This increase in the readily available $\mathrm{P}$ fraction in $\mathrm{BC}^{\text {plus }}$-treated soils was confirmed by linear combination fitting (LCF) analysis on $\mathrm{P} K$-edge XANES spectra of $\mathrm{BC}$ particles and amended soils. The proportion of Ca hydroxyapatite decreased, whereas the proportion of $\mathrm{CaHPO}_{4}$ increased in $\mathrm{BC}^{\text {plus }}$ particles after amended soils had been incubated and leached and cropped by ryegrass. Based on P XANES speciation as determined by LCF analysis, the proportion of inorganic $\mathrm{Ca}\left(\mathrm{H}_{2} \mathrm{PO}_{4}\right)_{2}$ increased in amended soils after $\mathrm{BC}^{\text {plus }}$ application. These results indicate that soil amendment with $\mathrm{BC}^{\text {plus }}$ particles leads to elevated $\mathrm{P}$ concentration and maintains more soluble $\mathrm{P}$ species than $\mathrm{BC}$ particles even after 230 days of ryegrass cultivation.
\end{abstract}

\section{Introduction}

On the global scale, readily available sources of phosphorus $(\mathrm{P})$, a crucial macronutrient element for agricultural production, are being faced with scarcity and overpricing (Scholz et al., 2013; Van Vuuren et al., 2010). Environmental pollution frequently arises from their impurities $(\mathrm{Cd}, \mathrm{U}$; Hartley et al., 2013; Kratz et al., 2016) and from over-fertilization (Rubaek et al., 2013). Further problems are the quick formation of stable and inaccessible compounds that limit plant $\mathrm{P}$ uptake (Shen et al., 2011) and the low agronomic efficiency of no more than $15 \%$ of fertilizer P in the first year of ap- plication (Schnug et al., 2003). Many recent studies have targeted sustainable agriculture through improving $\mathrm{P}$ availability from applied fertilizers (Delgado et al., 2002; Schröder et al., 2011), increasing P-uptake efficiency from organic and inorganic P pools in the soil (Kaur and Reddy, 2014) and developing new technologies for $\mathrm{P}$ recycling from human and animal waste (Siebers and Leinweber, 2013; Herzel et al., 2016). Particular attention has been paid to the oxidation process, e.g., by thiobacilli of elemental sulfur to sulfuric acid, in order to enhance the solubility of non-water-soluble $\mathrm{P}$ from 
rock phosphates (Powers, 1923; Lee et al., 1987; Fan et al., 2002) or meat and bone ashes (Schnug et al., 2003).

As an economically and environmentally attractive example, pyrolyzed animal bone chips branded as "bone char" (BC), a slow-release apatite-based P fertilizer, have been surface modified by sulfur (S) compounds to enhance its solubility in neutral to alkaline soils. Incubation-leaching and pot experiments confirmed that surface-modification was an effective approach in P-release promotion from BC fertilizer (Morshedizad et al., 2016; Zimmer, D. and Panten, K., personal communication). Such an in situ digestion of an apatitic phosphate with elemental $\mathrm{S}$ was first described by Fan et al. (2002, 2012).

Despite these attempts to raise the dissolution and use efficiency of $\mathrm{BC}$ in supplying $\mathrm{P}$ for crop requirements, a considerable fraction of applied BC-P to the soil remains insoluble in the short term and is not taken up by plants over the entire cropping period. A detailed $\mathrm{P}$ speciation can clarify the fate of insoluble $\mathrm{P}$ from $\mathrm{BC}$, which has not been done before.

Chemical speciation is described as the analytical identification of chemical species of defined elements and measuring their quantities in the system (Templeton et al., 2000). The precise characterization of various $\mathrm{P}$ species in the soil as a dynamic response to nonequilibrium conditions imposed by human activities, such as fertilization, can support a better understanding of reactivity, stability and particularly the plant accessibility of different $\mathrm{P}$ forms and provide a basis for best management practices. Several techniques, such as sequential fractionation (Dieter et al., 2010; Condron and Newman, 2011), nuclear magnetic resonance (NMR) spectroscopy (Liu et al., 2009; Vestergren et al., 2012; Ahlgren et al., 2013), Raman spectroscopy (Lanfranco, 2003; Vogel et al., 2013) and chromatography coupled to mass spectroscopy (De Brabandere et al., 2008; Paraskova et al., 2015), have been developed for P-speciation analysis in soil and sediments. Each one of these techniques can offer specific advantages and disadvantages depending on the phase and complexity of sample matrixes (Kruse et al., 2015). Complementarily, X-ray absorption near-edge structure (XANES) spectroscopy is well suited for the identification of various $\mathrm{P}$ species through the fingerprinting of molecular structures in solid and heterogeneous mediums based on fine features and the position of absorbing edges (Kelly et al., 2008; Kizewski et al., 2011). The advantages of XANES spectroscopy for soil samples make it a promising technique for direct and in situ $\mathrm{P}$ speciation with no pretreatment and minimal sample manipulation (Toor et al., 2006; Kelly et al., 2008).

According to the best of our knowledge, no studies have characterized $\mathrm{P}$-speciation changes in $\mathrm{BC}$ particles over nonequilibrium conditions in the soil system, and only few investigations have been reported on the $\mathrm{P}$ release from $\mathrm{BC}$ and alteration in P species of the soil. Siebers et al. (2013) investigated $K$-edge XANES spectroscopy on BC-incubated soil samples and provided evidence that the increase in extractable $\mathrm{Ca}$ and $\mathrm{Mg}$ phosphate fractions were related to the contribution of hydroxyapatite (HAP) increase after BC application. Accordingly, the objective of this study was to provide practical information on the fate and alteration of $\mathrm{P}$ species in BC and novel surface-modified BC (BC $\left.{ }^{\text {plus }}\right)$ particles and their treated soils under incubation-leaching and ryegrass cultivation practices using sequential $\mathrm{P}$ fractionation and P XANES spectroscopy.

\section{Materials and methods}

\subsection{Incubation-leaching experiment}

Two particle size fractions (1-2 and 2-4 mm) of bone chars were incubated with a silt loam soil (BC produced by the pyrolysis of degreased animal bone chips at $800^{\circ} \mathrm{C}$ and $\mathrm{BC}^{\text {plus }}$ as a surface-modified $\mathrm{BC}$ obtained by blending with reduced S-containing compounds composed of $60 \%$ elemental S, $30 \%$ calcium sulfate dehydrate and $10 \%$ methanesulfonate (Zimmer et al., unpublished results of $\mathrm{S}$ $\mathrm{X}$-ray absorption near-edge fine structure spectroscopy) in a commercial biogas desulfurization process; patent application DE 212012000046U1; http:www.google.com/patents/ DE212012000046U1?cl=en\&hl=de). The soil was classified as Dystric Cambisol (FAO) with a pH of 4.7 (measured in $0.01 \mathrm{~mol} \mathrm{~L}^{-1} \mathrm{CaCl}_{2}$ solution) and total (digestion with $\mathrm{HNO}_{3}$ and analyzed using ICP-OES; USEPA, 1997) and available (extracted by $1 \mathrm{~mol} \mathrm{~L}^{-1} \mathrm{NH}_{4} \mathrm{NO}_{3}$ and analyzed using ICP-OES; He and Singh, 1993) $\mathrm{P}$ contents of $1.6 \mathrm{~g} \mathrm{P} \mathrm{kg}^{-1}$ and $14 \mathrm{mg} \mathrm{P} \mathrm{kg}^{-1}$, respectively. The $\mathrm{BC}$ and $\mathrm{BC}^{\text {plus }}$ contained a total $\mathrm{P}$ of 149 and $123 \mathrm{~g} \mathrm{~kg}^{-1}$, total calcium (Ca) of 185 and $265 \mathrm{~g} \mathrm{~kg}^{-1}$ and total $\mathrm{S}$ of 6 and $199 \mathrm{~g} \mathrm{~kg}^{-1}$ with average $\mathrm{pH}_{\mathrm{CaCl}_{2}}$ values of 7.8 and 4.9 , respectively.

The BCs were added to $30 \mathrm{~g}$ of air dry soil $(<2 \mathrm{~mm})$ at levels of $0 \mathrm{mg} \mathrm{P} \mathrm{kg}^{-1}$ soil (control) and $500 \mathrm{mg} \mathrm{P} \mathrm{kg}^{-1}$ in five replicates. The soil and $\mathrm{BC}-\mathrm{BC}^{\text {plus }}$ mixture was homogenized and packed into glass columns with a $10 \mathrm{~cm}$ length and an inner diameter of $2 \mathrm{~cm}$. A P-free filter (MN $616 \mathrm{G}$; Macherey-Nagel GmbH \& Co., KG Düren, Germany) was placed at the bottom of each column to avoid any particle losses. The amended soils were incubated for 70 days at $20^{\circ} \mathrm{C}$ in the dark and constant soil moisture between 60 and $70 \%$ of soil-water-holding capacity. During the incubation period, the soil columns were leached with three pore volumes of deionized water added by a droplet irrigation simulator system. The leaching process was repeated in five steps, each one after $1,5,13,34$ and 70 days. The $\mathrm{P}$ concentrations in collected leachates were measured using inductively coupled plasma-optical emission spectrometry (ICP-OES). The outcomes of the leaching experiment were described in Morshedizad and Leinweber (2017). After the incubationleaching experiment, the treated soil samples were carefully removed from the glass columns and air-dried, and the $\mathrm{BC}-$ $\mathrm{BC}^{\text {plus }}$ particles were manually separated from the soils very gently. The BC-BC ${ }^{\text {plus }}$ particles were delicately washed with deionized water to remove adhered soil particles, allowed to 
dry completely at ambient conditions and finely ground for further analyses.

\subsection{Pot experiment with annual ryegrass}

The same $\mathrm{BC}$ and $\mathrm{BC}^{\text {plus }}$ as described for the incubationleaching experiment were used in original sizes (mostly between 1 and $5 \mathrm{~mm}$ ) for the $\mathrm{P}$ fertilization of annual ryegrass in a pot experiment. The experiment was set up using an acidic sandy silt soil with an available $\mathrm{P}$ content of $24.2 \mathrm{mg} \mathrm{P} \mathrm{kg}^{-1}$ and a $\mathrm{pH}$ of 5.2. The pot experiment was set up by adding $\mathrm{BC}$ and $\mathrm{BC}^{\text {plus }}$ at the levels of $0 \mathrm{mg} \mathrm{Pkg}^{-1}$ (control) and $280 \mathrm{mg} \mathrm{P} \mathrm{kg}^{-1}$ into the $6 \mathrm{~kg}$ of the soil dry matter in each pot and in four replicates arranged in a completely randomized block. After 4 weeks of incubation at field capacity water content and ambient temperature conditions, 30 seeds of annual ryegrass per pot were sown on 13 May 2016. The experiment was conducted in a glasshouse under ambient air and temperature conditions and the soil moisture was maintained at field capacity during the whole experiment. All other essential nutrients were sequentially added at sufficient levels before seeding and after six cuts of ryegrass between 23 June and 3 November 2016. Finally, after the last harvest (the seventh), plant parts (shoots and roots) were dried at $60^{\circ} \mathrm{C}$ and $\mathrm{BC}$ particles were manually separated from the soils (as they could be detected visually by their size and dark color) very gently using tweezers. Then these particles were washed delicately with deionized water to remove attached soil particles, allowed to dry completely at ambient conditions and finely ground to fine powders for further analyses.

\subsection{Sequential phosphorus fractionation}

Soil samples were sequentially extracted based on chemical solubility in order according to a modified Hedley et al. (1982) procedure. After BC-BC ${ }^{\text {plus }}$ particle detachment, duplicate $0.5 \mathrm{~g}$ fine-ground and air-dried soil samples were weighed into $50 \mathrm{~mL}$ centrifuge tubes. In summary, chemical $\mathrm{P}$ fractionation included the following steps.

1. The mobile and readily available $\mathrm{P}$ fraction was extracted with resin strips (saturated in $0.5 \mathrm{M} \mathrm{NaHCO}_{3}$ ) after $18 \mathrm{~h}$ of end-over-end shaking in $30 \mathrm{~mL}$ of deionized water. The resin strips were separated from solids and the solution and washed using $50 \mathrm{~mL}$ of $1 \mathrm{M} \mathrm{HCl}$ to remove absorbed $\mathrm{P}$. The soil suspension was centrifuged at $2500 \times g$ for $20 \mathrm{~min}$ and the supernatant was decanted.

2. Next, the labile inorganic and organic fractions weakly absorbed to mineral surfaces and some microbial $\mathrm{P}$ were extracted by $30 \mathrm{~mL}$ of $0.5 \mathrm{M} \mathrm{NaHCO}_{3}, 18 \mathrm{~h}$ of end-overend shaking and centrifugation at $2500 \times g$ for $20 \mathrm{~min}$. The supernatant was filtered (Whatman no. 42 filter) and collected for measurements.
3. The inorganic P adsorbed and bound to Al- and Feoxide minerals and organic $\mathrm{P}$ from humic substances were extracted using $30 \mathrm{~mL}$ of $0.1 \mathrm{M} \mathrm{NaOH}$ solution and repeating the second step as described above.

4. The relatively insoluble fraction of $\mathrm{P}$ bound to $\mathrm{Ca}$ and $\mathrm{Mg}$ minerals and apatite was extracted by $30 \mathrm{~mL}$ of $1 \mathrm{M} \mathrm{HCl}$ in the same way as in the previous steps.

Total $\mathrm{P}$ concentrations $\left(\mathrm{P}_{\mathrm{t}}\right)$ and inorganic $\mathrm{P}\left(\mathrm{P}_{\mathrm{i}}\right)$ in all extracts were measured by ICP-OES and colorimetrically (molybdenum blue method; Murphy and Riley, 1962), respectively. The organic $\mathrm{P}\left(\mathrm{P}_{\mathrm{O}}\right)$ concentrations were calculated by using $\mathrm{P}_{\mathrm{t}}-\mathrm{P}_{\mathrm{i}}$.

\subsection{Phosphorus $K$-edge XANES analysis}

The XANES data collection for characterizing $\mathrm{P}$ species in all soil samples and $\mathrm{BC}-\mathrm{BC}{ }^{\text {plus }}$ particles was acquired at the Synchrotron Light Research Institute (SLRI) in Nakhon Ratchasima, Thailand on the beamline 8 (BL8) of the electron storage ring with a covering photon energy from 1.25 to $10 \mathrm{KeV}$, electron energy operated at $1.2 \mathrm{GeV}$ and a beam current of $80-150 \mathrm{~mA}$ (Klysubun et al., 2012). The P $K$-edge XANES spectra were collected from dried and very finely ground treated soils and particulate $\mathrm{BC}-\mathrm{BC}^{\text {plus }}$ samples that had been diluted to $\mathrm{P}$ concentrations $<10 \mathrm{mg} \mathrm{Pkg}^{-1}$ with $\mathrm{SiO}_{2}$ powder (to eliminate self-absorption effects; Prietzel et al., 2013), again ground in an agate stone mini-mortar and spread uniformly as a thin layer on P-free kapton tape (Lanmar Inc., Northbrook, IL, USA). Data collection was operated in standard conditions with energy calibration by standard pure elemental $\mathrm{P}$ and allocating the reference energy $\left(E_{0}\right)$ at $2145.5 \mathrm{eV}$ using the maximum peak of the firstderivative spectrum. All spectra were recorded at photon energies between 2045.5 and $2495.5 \mathrm{eV}$ in step sizes of $5 \mathrm{eV}$ (2045.5 to $2105.5 \mathrm{eV}$ and 2245.5 to $2495.5 \mathrm{eV}$ ), $1 \mathrm{eV}$ (2105.5 to $2135.5 \mathrm{eV}$ and 2195.5 to $2245.5 \mathrm{eV}$ ) and $0.25 \mathrm{eV}$ (2135.5 to $2195.5 \mathrm{eV}$ ) with a 13 -channel germanium detector in fluorescence mode. At least three scans were collected and averaged for each sample.

The $\mathrm{P}$ XANES spectra were normalized, and after merging replicates a linear combination fitting (LCF) was performed using the ATHENA software package (Ravel and Newville, 2005). All XANES spectral data were baseline corrected in the pre-edge region between 2115 and $2145 \mathrm{eV}$ and normalized in the post-edge region of $2190-2215 \mathrm{eV}$. The same ranges were used for the reference $\mathrm{P} K$-edge XANES spectra to achieve consistency in the following fitting analysis (Prietzel et al., 2016). To achieve the best compatible set of references with each specified sample spectrum, LCF analysis was performed in the energy range between $-20 \mathrm{eV}$ and $+30 \mathrm{eV}$ relative to the $\mathrm{E}_{0}$ using the combinatorics function of ATHENA software to attain all possible binary, ternary and at most quaternary combinations between all $19 \mathrm{P}$ reference spectra. The following set of 
Table 1. Distribution of inorganic $P\left(P_{i}\right)$, organic $P\left(P_{0}\right)$ and total $P\left(P_{t}\right)$ concentrations $\left(\mathrm{mg} \mathrm{Pkg}^{-1}\right.$ soil $)$ of sequentially extracted $P$ fractions in the soils as affected by different treatments (treated with two particle size fractions (1-2 and $2-4 \mathrm{~mm})$ and original sizes of $\mathrm{BC}$ and $\mathrm{BC}$ plus or unfertilized soils (control) after incubation-leaching and ryegrass cultivation experiments).

\begin{tabular}{|c|c|c|c|c|c|c|c|c|c|c|c|c|}
\hline \multirow{2}{*}{ Treatment } & \multicolumn{3}{|c|}{ Resin P } & \multicolumn{3}{|c|}{$\mathrm{NaHCO}_{3}-\mathrm{P}$} & \multicolumn{3}{|c|}{$\mathrm{NaOH}-\mathrm{P}$} & \multicolumn{3}{|c|}{$\mathrm{HCl}-\mathrm{P}$} \\
\hline & $\mathrm{P}_{\mathrm{i}}$ & $\mathrm{P}_{\mathrm{o}}$ & $\mathrm{P}_{\mathrm{t}}$ & $\mathrm{P}_{\mathrm{i}}$ & $\mathrm{P}_{\mathrm{o}}$ & $\mathrm{P}_{\mathrm{t}}$ & $\mathrm{P}_{\mathrm{i}}$ & $\mathrm{P}_{\mathrm{o}}$ & $\mathrm{P}_{\mathrm{t}}$ & $\mathrm{P}_{\mathrm{i}}$ & $\mathrm{P}_{\mathrm{o}}$ & $\mathrm{P}_{\mathrm{t}}$ \\
\hline \multicolumn{13}{|c|}{ Incubation leaching } \\
\hline Control & 47 & 5 & 52 & 160 & 99 & 259 & 565 & 294 & 859 & 113 & 10 & 123 \\
\hline $\mathrm{BC}_{1-2 \mathrm{~mm}}$ & $56^{\mathrm{NS}}$ & $7^{\mathrm{NS}}$ & $63^{\mathrm{NS}}$ & $163^{\mathrm{NS}}$ & $108^{\mathrm{NS}}$ & $271^{\mathrm{NS}}$ & $578^{\mathrm{NS}}$ & $303^{\mathrm{NS}}$ & $881^{\mathrm{NS}}$ & $140^{\mathrm{NS}}$ & $56^{\mathrm{NS}}$ & $196^{\mathrm{NS}}$ \\
\hline $\mathrm{BC}_{2}-4 \mathrm{~mm}$ & $50^{\mathrm{NS}}$ & $7^{\mathrm{NS}}$ & $57^{\mathrm{NS}}$ & $161^{\mathrm{NS}}$ & $105^{\mathrm{NS}}$ & $266^{\mathrm{NS}}$ & $574^{\mathrm{NS}}$ & $301^{\mathrm{NS}}$ & $875^{\mathrm{NS}}$ & $121^{\mathrm{NS}}$ & $40^{\mathrm{NS}}$ & $161^{\mathrm{NS}}$ \\
\hline $\mathrm{BC}_{1-2 \mathrm{~mm}}^{\text {plus }}$ & $61^{*}$ & $7^{\mathrm{NS}}$ & $68^{\mathrm{NS}}$ & $172^{\mathrm{NS}}$ & $111^{\mathrm{NS}}$ & $283^{\mathrm{NS}}$ & $593^{*}$ & $313^{\mathrm{NS}}$ & $906^{*}$ & $131^{\mathrm{NS}}$ & $37^{\mathrm{NS}}$ & $170^{\mathrm{NS}}$ \\
\hline $\mathrm{BC}_{2-4 \mathrm{~mm}}^{\text {plus }}$ & $50^{\mathrm{NS}}$ & $7^{\mathrm{NS}}$ & $57^{\mathrm{NS}}$ & $160^{\mathrm{NS}}$ & $104^{\mathrm{NS}}$ & $264^{\mathrm{NS}}$ & $574^{\mathrm{NS}}$ & $298^{\mathrm{NS}}$ & $872^{\mathrm{NS}}$ & $115^{\mathrm{NS}}$ & $21^{\mathrm{NS}}$ & $135^{\mathrm{NS}}$ \\
\hline \multicolumn{13}{|c|}{ Ryegrass cropping experiment } \\
\hline Control & 4 & 4 & 8 & 25 & 27 & 52 & 75 & 121 & 196 & 28 & 5 & 33 \\
\hline $\mathrm{BC}$ & $2^{\mathrm{NS}}$ & $5^{\mathrm{NS}}$ & $7^{\mathrm{NS}}$ & $24^{\mathrm{NS}}$ & $32^{\mathrm{NS}}$ & $56^{\mathrm{NS}}$ & $79^{\mathrm{NS}}$ & $125^{\mathrm{NS}}$ & $204^{\mathrm{NS}}$ & $30^{\mathrm{NS}}$ & $6^{\mathrm{NS}}$ & $36^{\mathrm{NS}}$ \\
\hline $\mathrm{BC}^{\text {plus }}$ & $6^{*}$ & $5^{\mathrm{NS}}$ & $11^{*}$ & $35^{\mathrm{NS}}$ & $27^{\mathrm{NS}}$ & $62^{\mathrm{NS}}$ & $85^{* *}$ & $128^{\mathrm{NS}}$ & $213^{\mathrm{NS}}$ & $34^{\mathrm{NS}}$ & $7^{\mathrm{NS}}$ & $41^{\mathrm{NS}}$ \\
\hline
\end{tabular}

* Significant at $P<0.05 ;{ }^{*}$ Significant at $P<0.01$; NS Nonsignificant difference (treatment vs. control; Tukey's test)

reference P $K$-edge XANES spectra, all recorded in SLRI under the same adjustments by Werner and Prietzel (2015) and Prietzel et al. (2016), were used for fitting and calculations; $\mathrm{Ca}, \mathrm{Al}$ and $\mathrm{Fe}$ phytate, noncrystalline and crystalline $\mathrm{AlPO}_{4}$, noncrystalline and crystalline $\mathrm{FePO}_{4} \cdot 2 \mathrm{H}_{2} \mathrm{O}, \mathrm{Ca}$ hydroxyapatite $\left(\mathrm{Ca}_{5}(\mathrm{OH})\left(\mathrm{PO}_{4}\right)_{3}\right)$, inositol hexakisphosphate (IHP), ferrihydrite-IHP, montmorillonite-Al-IHP, soil organic matter Al-IHP (SOM-Al-IHP), ferrihydriteorthophosphate, montmorillonite-Al-orthophosphate, SOM-Al-orthophosphate, IHP, orthophosphate, $\mathrm{CaHPO}_{4}$, $\mathrm{Ca}\left(\mathrm{H}_{2} \mathrm{PO}_{4}\right)_{2}$ and $\mathrm{MgHPO}_{4}$. To select the best possible combination fit between the sample spectrum and the $\mathrm{P}$ reference spectra, the lowest reduced chi value $\left(\chi^{2}\right)$ and $R$ factor were chosen.

\section{Results}

\subsection{Effect of BCs on sequentially extracted $\mathrm{P}$ after incubation leaching}

After 70 days of incubation leaching, the sequential $\mathrm{P}$ fractionation of amended soils showed variations in the amount and distribution of various $\mathrm{P}$ fractions between different treatments (Table 1). For all treatments, $\mathrm{NaOH}$ extracted the majority of fractionated P (62.4 to $66.5 \%$ of total fractionated $\mathrm{P})$, followed by the labile $\mathrm{P}$ fraction $\left(\mathrm{NaHCO}_{3}, 19.2\right.$ to $20.0 \%)$, $\mathrm{HCl}-\mathrm{P}(9.5$ to $13.9 \%)$ and the readily available $\mathrm{P}$ (resin strips, 4.1 to $4.8 \%$ ). The $\mathrm{BC}-\mathrm{BC}^{\text {plus }}$ addition increased the total soil $\mathrm{P}$ pools although the difference was significant only for the $\mathrm{BC}_{1-2 \mathrm{~mm}}^{\text {plus }}$ and $\mathrm{BC}_{1-2 \mathrm{~mm}}$ treatments. The largest increase in total fractionated $\mathrm{P}_{\mathrm{t}}$ (resin $\mathrm{P}_{\mathrm{t}}+\mathrm{NaHCO}_{3}-\mathrm{P}_{\mathrm{t}}+\mathrm{NaOH}-\mathrm{P}_{\mathrm{t}}+\mathrm{HCl}-\mathrm{P}_{\mathrm{t}}$ ) occurred in $\mathrm{BC}_{1-2 \mathrm{~mm}}^{\text {plus }}\left(133.8 \mathrm{mg} \mathrm{kg}^{-1}\right.$ soil $)$, followed by $\mathrm{BC}_{1-2 \mathrm{~mm}}$
(118.6 $\mathrm{mg} \mathrm{Pg}^{-1}$ soil), $\mathrm{BC}_{2-4 \mathrm{~mm}}\left(67.1 \mathrm{mg} \mathrm{Pkg}^{-1}\right.$ soil) and $\mathrm{BC}_{2-4 \mathrm{~mm}}^{\text {plus }}\left(35.7 \mathrm{mg} \mathrm{Pkg}^{-1}\right.$ soil $)$ compared to the control soil.

The proportion of $\mathrm{P}$ enrichment in each fraction varied between different treatments in the order $\mathrm{NaOH}-\mathrm{P}>\mathrm{HCl}-$ $\mathrm{P}>\mathrm{NaHCO}_{3}-\mathrm{P}>$ resin $\mathrm{P}$ for $\mathrm{BC}_{1-2 \mathrm{~mm}}^{\text {plus }}$ and $\mathrm{BC}_{2-4 \mathrm{~mm}}^{\text {plus }}$. For the $\mathrm{BC}_{1-2 \mathrm{~mm}}$ and $\mathrm{BC}_{2-4 \mathrm{~mm}}$ treatment the order was $\mathrm{HCl}-$ $\mathrm{P}>\mathrm{NaOH}-\mathrm{P}>\mathrm{NaHCO}_{3}-\mathrm{P}>$ resin $\mathrm{P}$. In all treatments, the $P_{i}$ proportions in each of the $P$ fractions were greater than the $\mathrm{P}_{\mathrm{o}}$ proportions. Compared to the control soil, the most $\mathrm{P}_{\mathrm{i}}$ increase was observed in $\mathrm{NaOH}-\mathrm{P}_{\mathrm{i}}$ and resin $\mathrm{P}_{\mathrm{i}}$ in response to $\mathrm{BC}_{1-2 \mathrm{~mm}}^{\text {plus }}$ application (Table 1). Moreover, after 70 days of incubation leaching, soil $\mathrm{pH}$ increased in $\mathrm{BC}$ treatments whereas $\mathrm{BC}^{\text {plus }}$ amendments had an acidifying effect. Soil $\mathrm{pH}$ levels of $\mathrm{BC}_{1-2 \mathrm{~mm}}$ and $\mathrm{BC}_{2-4 \mathrm{~mm}}$ increased by 0.07 and 0.05 units and decreased for $\mathrm{BC}_{1-2 \mathrm{~mm}}^{\text {plus }}$ and $\mathrm{BC}_{2-4 \mathrm{~mm}}^{\text {plus }}$ treatments by 0.21 and 0.15 units compared to unamended control soil $(\mathrm{pH}=5.06)$.

\subsection{Effect of BCs on sequentially extracted $\mathrm{P}$ after ryegrass cropping}

Sequentially extracted $\mathrm{P}$ fractions in soil varied between different treatments after 230 days of ryegrass cropping (Table 1). In all treatments (control, $\mathrm{BC}$ and $\mathrm{BC}^{\text {plus }}$ ), $\mathrm{NaOH}-$ $\mathrm{P}$ was the largest $\mathrm{P}$ pool mainly associated with $\mathrm{Al}-$ and Fe-oxide minerals and humic substances $(65.0$ to $67.5 \%$ of total fractionated $\mathrm{P}$ ), followed by the $\mathrm{NaHCO}_{3}-\mathrm{P}$ (18.2 to $19.0 \%), \mathrm{HCl}-\mathrm{P}(11.5$ to $12.6 \%)$ and resin $\mathrm{P}(2.2$ to $3.4 \%)$ fractions. Enrichments of $\mathrm{P}$ fractions in $\mathrm{BC}^{\text {plus }}$ treatments were more pronounced than in treated soils with $\mathrm{BC}$ particles. In this treatment the concentrations of readily available and labile inorganic $\mathrm{P}$ fractions were insignificantly smaller than in the control. Additionally, a significant in- 
crease in $\mathrm{P}$ concentration was obtained only in resin $\mathrm{P}_{\mathrm{i}}$ and $\mathrm{NaOH}-\mathrm{P}_{\mathrm{i}}$ fractions of the $\mathrm{BC}^{\text {plus }}$-treated soil (Table 1). The maximum increase in total fractionated $\mathrm{P}$ was obtained in the $\mathrm{BC}^{\text {plus }}$ treatment $\left(37.6 \mathrm{mg} \mathrm{P} \mathrm{kg}^{-1}\right.$ soil). In comparison to incubation-leaching results, a similar sequence was observed for the order of increasing magnitude of $\mathrm{P}$ fractions in response to $\mathrm{BC}$ and $\mathrm{BC}^{\text {plus }}$ amendments $(\mathrm{NaOH}-$ $\mathrm{P}>\mathrm{NaHCO}_{3}-\mathrm{P}>\mathrm{HCl}-\mathrm{P}>$ resin $\mathrm{P}$ ). However, for $\mathrm{BC}$ treatment, the total $\mathrm{P}$ extracted by resin strips was lowered in comparison with the control. In the control and $\mathrm{BC}$ treatments, $\mathrm{P}_{\mathrm{O}}$ was the predominant form in $\mathrm{NaOH}-\mathrm{P}$ and $\mathrm{NaHCO}_{3}-\mathrm{P}$ fractions, while for BCplus it was only in the $\mathrm{NaOH}-\mathrm{P}$ fraction. Each $\mathrm{P}$ fraction was highest under $\mathrm{BC}^{\text {plus }}$ application, except for $\mathrm{NaHCO}_{3}-\mathrm{P}_{\mathrm{O}}$ in the $\mathrm{BC}$ treatment.

Separately, the effect of $\mathrm{BC}$ and $\mathrm{BC}^{\text {plus }}$ application on ryegrass yield parameters was examined in the 230-day pot experiment. The results indicated that the $\mathrm{P}$ uptake, ryegrass yield and apparent nutrient recovery efficiency (ANR) of $\mathrm{BC}^{\text {plus }}$ treatments exceeded those of the $\mathrm{BC}$ and control treatments and increased to values comparable with triple superphosphate (TSP) fertilizer (Zimmer, D. and Panten, K., personal communication). The addition of $\mathrm{BC}$ and $\mathrm{BC}^{\text {plus }}$ did not significantly change the bulk soil $\mathrm{pH}$, although local acidification around $\mathrm{BC}^{\text {plus }}$ particles ( $\mathrm{pH} 4.9$; Morshedizad and Leinweber, 2017) can probably lower soil pH in small-scale areas compared to $\mathrm{BC}$ treatments ( $\mathrm{pH}$ about 8 ).

\subsection{XANES analysis of BC-BC plus particles}

All spectra from BCs were characterized by an intense whiteline peak, a post-edge position and no distinct pre-edge, which corresponded to calcium phosphate compounds including $\mathrm{Ca}$ hydroxyapatite, dicalcium phosphate $\left(\mathrm{CaHPO}_{4}\right)$ and Ca phytate (Fig. 1). The P $K$-edge XANES results indicated no obvious alterations in the spectral features of $\mathrm{BC}-$ $\mathrm{BC}^{\text {plus }}$ particles after the incubation-leaching experiment. After 70 days of incubation leaching, the BC spectra were shifted towards $\mathrm{Ca}$ hydroxyapatite, and this was more pronounced for the 2-4 mm than for the 1-2 mm BC particles. The opposite trend was the case for $\mathrm{BC}^{\text {plus }}$ particles; the white-line signal intensity decreased after the incubationleaching period and the post-edge of the spectra tended more to dicalcium phosphate. This effect was stronger for $\mathrm{BC}^{\text {plus }}$ particle size reduction from $2-4 \mathrm{~mm}$ to $1-2 \mathrm{~mm}$.

To quantify the $\mathrm{P}$ speciation of $\mathrm{BC}$ and $\mathrm{BC}$ plus particles, LCF analyses using all possible combinations were performed on all $\mathrm{P} K$-edge XANES spectra (Table 2). The fitting results indicated that untreated $\mathrm{BC}$ and $\mathrm{BC}^{\text {plus }}$ particles before the experiment contained on average 61 and $60 \% \mathrm{Ca}$ hydroxyapatite, 22 and $30 \% \mathrm{CaHPO}_{4}$ and 18 and $10 \% \mathrm{Ca}$ phytate. After 70 days of incubation leaching, the proportion of Ca hydroxyapatite increased to the average of $80 \%$ in $\mathrm{BC}$, while it remained unchanged in $\mathrm{BC}^{\text {plus }}$ particles. The $\mathrm{CaHPO}_{4}$ proportion increased in $\mathrm{BC}^{\text {plus }}$ particles to the average of $34 \%$, whereas the lower content was assigned in the spectra of BC particles accounting for $10 \%$ of total $\mathrm{P}$ species. Moreover, the $\mathrm{Ca}$ phytate proportion decreased slightly in $\mathrm{BC}$ and $\mathrm{BC}^{\text {plus }}$ particles from about 18 and $10 \%$ to averages of 11 and $7 \%$, respectively.

Spectra of $\mathrm{BC}$ and $\mathrm{BC}^{\text {plus }}$ particles before and after 230 days of ryegrass cultivation were characterized by a sharp white line, followed by a shoulder and then a postedge feature between 2160 and $2175 \mathrm{eV}$, which was divided into two peaks (Fig. 2). These features were most similar to the $\mathrm{P} K$-edge XANES spectra of Ca hydroxyapatite, $\mathrm{CaHPO}_{4}$ and $\mathrm{Ca}$ phytate standard compounds. Treated BC particles had a white line with higher intensity that appeared more similar to the Ca hydroxyapatite spectrum. In contrast, $\mathrm{BC}^{\text {plus }}$ particles under ryegrass cultivation showed a weaker white line exhibiting the shoulder and post-edge feature more comparable to the $\mathrm{CaHPO}_{4}$ spectrum.

Some differences in the proportions of $\mathrm{P}$ species observed between $\mathrm{BC}-\mathrm{BC}^{\text {plus }}$ particles before and after the cropping period in the ryegrass pot experiment are presented in $\mathrm{Ta}$ ble 3. The LCF results revealed overall contributions of 63 and $70 \%$ Ca hydroxyapatite, 29 and $29 \% \mathrm{CaHPO}_{4}$ and 8 and $1 \% \mathrm{Ca}$ phytate in the original $\mathrm{BC}$ and $\mathrm{BC}^{\text {plus }}$, respectively. After the cropping period, the percentage of $\mathrm{Ca}$ hydroxyapatite was increased in $\mathrm{BC}$ particles. In the $\mathrm{BC}^{\text {plus }}$ treatment, the percentage of $\mathrm{CaHPO}_{4}$ increased from 29 to 43, while the percentage of $\mathrm{Ca}$ hydroxyapatite was reduced from 70 to $49 \%$. The Ca phytate proportion remained unchanged in $\mathrm{BC}$ particles, while that of $\mathrm{BC}^{\text {plus }}$ increased from 1 to $8 \%$ after the ryegrass cultivation period.

\subsection{XANES analysis of soil samples}

The $\mathrm{P} K$-edge XANES spectra of soil samples from the incubation-leaching experiment showed two dominant features: (1) a strong white line lacking a pre-edge and shoulder and (2) a tailed post-edge feature (Fig. 3). The most similarity to these features was seen in XANES spectra of amorphous $\mathrm{AlPO}_{4}, \mathrm{FePO}_{4}$ and SOM-Al-IHP compounds. Distinct differences appeared between the control and treated soil with $\mathrm{BC}^{\text {plus }}$, not with BC treatments. This was reflected by slightly lower intensities of both white-line and post-edge features.

The $\mathrm{P}$ species of treated soils in the incubation-leaching experiment were determined by LCF analysis to select at most four reference compounds in the combinatorics of all possible fitting combinations (Table 4). The fitting results indicated that $\mathrm{P}$ in the control soil and $\mathrm{BC}$ treatments occurred dominantly as amorphous $\mathrm{AlPO}_{4}(\approx 40 \%), \mathrm{FePO}_{4}(\approx 30 \%)$ and SOM-Al-IHP $(\approx 20 \%)$ compounds. In BC Blus $^{\text {treated }}$ soils, the average proportion of amorphous $\mathrm{AlPO}_{4}$ decreased to $26 \%$, and instead $\mathrm{Ca}\left(\mathrm{H}_{2} \mathrm{PO}_{4}\right)_{2}$ was identified with an average of $25 \%$, which did not appear in the control and $\mathrm{BC}$ treatments. The LCF results showed that the soil treated with $\mathrm{BC}^{\text {plus }}$ had no detectable $\mathrm{Ca}$ hydroxyapatite, which was found in the control and $\mathrm{BC}$ treatments. 

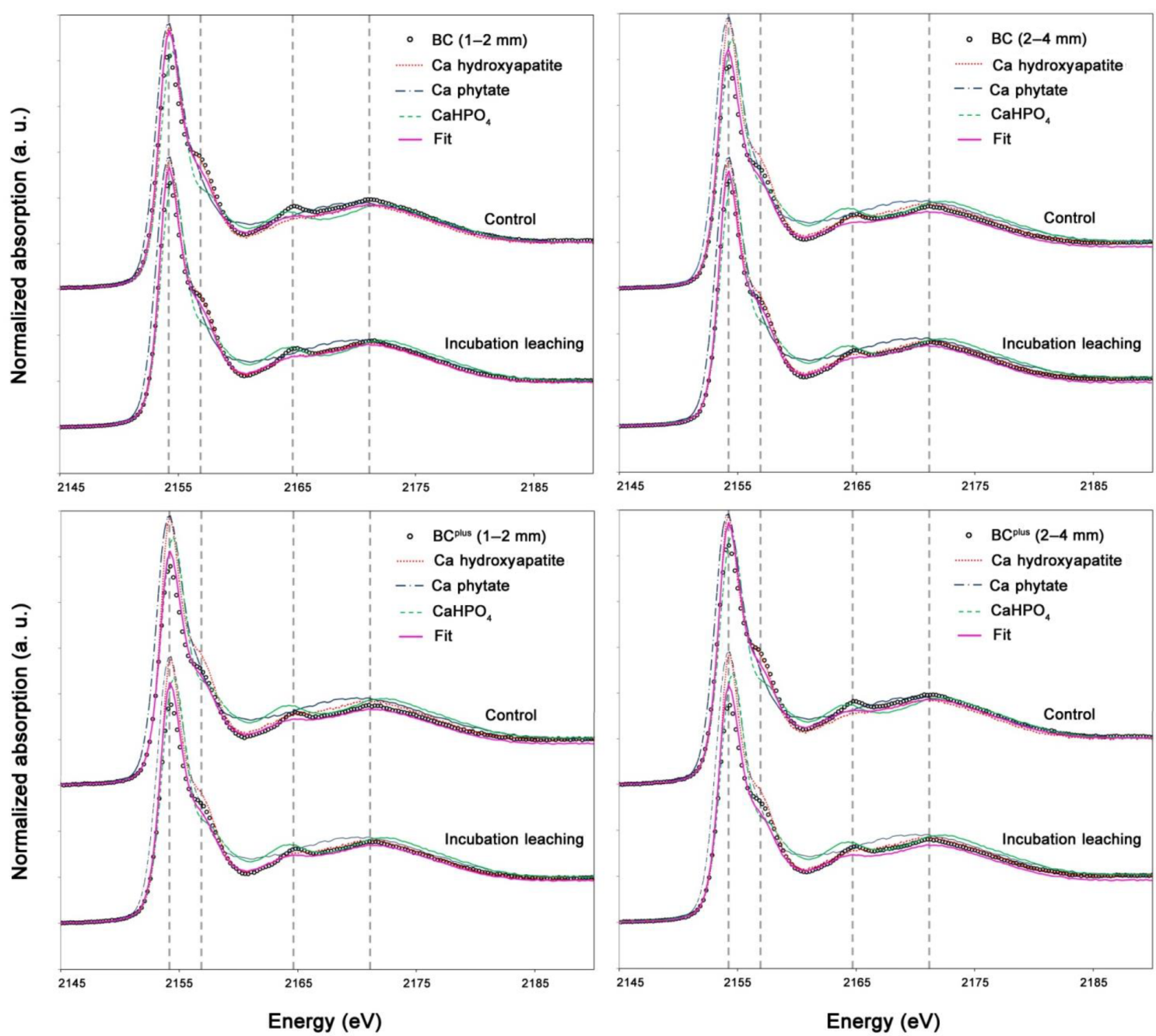

Figure 1. Normalized $\mathrm{P} K$-edge XANES spectra of different $\mathrm{BC}$ and $\mathrm{BC}^{\text {plus }}$ particle sizes (1-2 and 2-4 mm) before (control) and after a 70-day incubation-leaching experiment compared to the reference compounds selected using the LCF method.
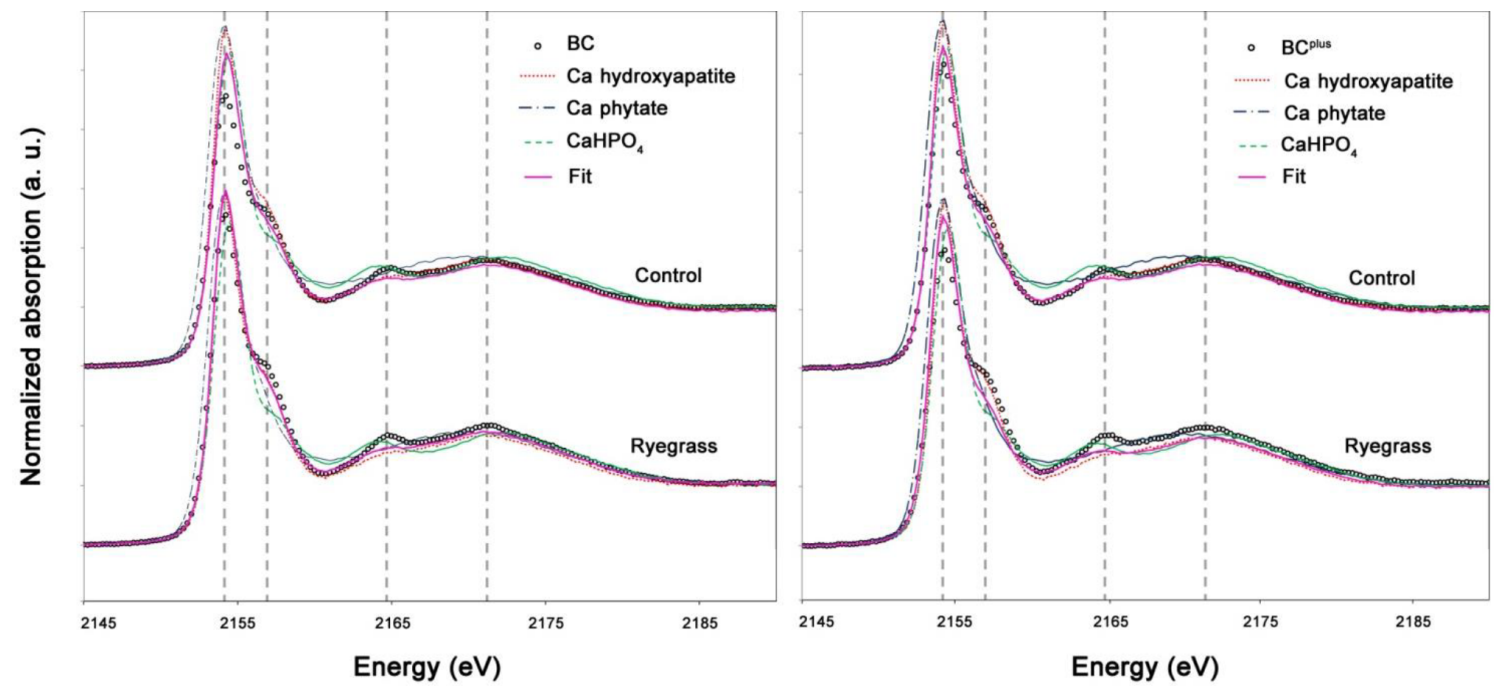

Figure 2. $\mathrm{P} K$-edge XANES spectra of $\mathrm{BC}$ and $\mathrm{BC}^{\text {plus }}$ particles before (control) and after 230 days of ryegrass cultivation compared to the reference compounds selected by the LCF method. 

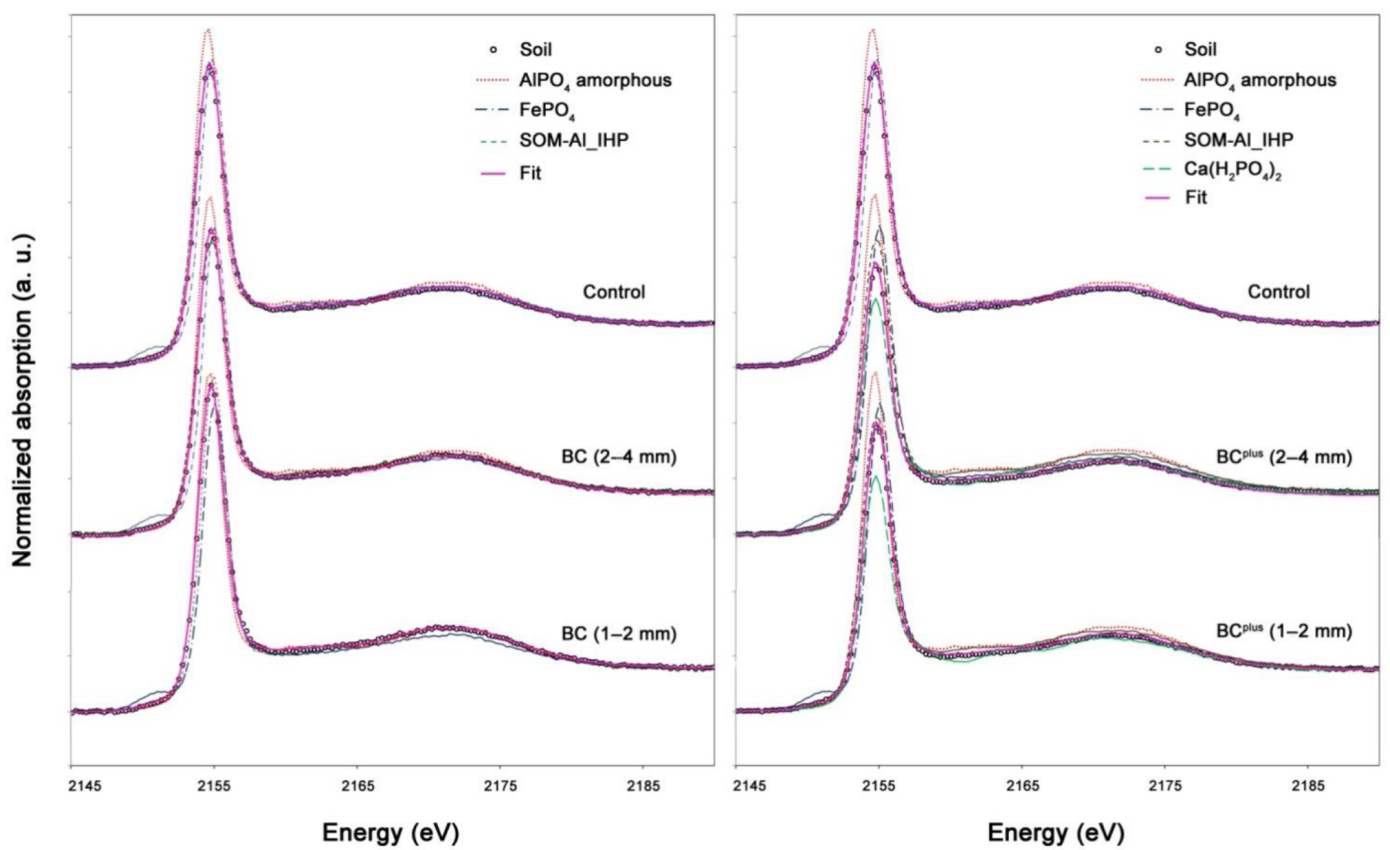

Figure 3. P $K$-edge XANES spectra of unfertilized (control) and fertilized soils with BC and BC ${ }^{\text {plus }}$ particles under a 70-day incubationleaching experiment compared to the reference compounds selected by the LCF method.

Table 2. Results of linear combination fitting (LCF) conducted on P $K$-edge XANES spectra of bone char (BC) and surface-modified bone char $\left(\mathrm{BC}^{\text {plus }}\right)$ particles before and after a 70-day incubation-leaching period. These best fits were achieved using all possible combinations with 19 spectra of $\mathrm{P}$ reference compounds.

\begin{tabular}{|c|c|c|c|c|c|c|c|c|}
\hline \multirow{3}{*}{ Reference compound } & \multicolumn{4}{|c|}{ Before experiment } & \multicolumn{4}{|c|}{ After 70 days of incubation leaching } \\
\hline & \multicolumn{2}{|c|}{$\mathrm{BC}$} & \multicolumn{2}{|c|}{$\mathrm{BC}^{\text {plus }}$} & \multicolumn{2}{|c|}{$\mathrm{BC}$} & \multicolumn{2}{|c|}{$\mathrm{BC}^{\text {plus }}$} \\
\hline & $1-2 \mathrm{~mm}$ & $2-4 \mathrm{~mm}$ & $1-2 \mathrm{~mm}$ & $2-4 \mathrm{~mm}$ & $1-2 \mathrm{~mm}$ & $2-4 \mathrm{~mm}$ & $1-2 \mathrm{~mm}$ & $2-4 \mathrm{~mm}$ \\
\hline Ca hydroxyapatite (\%) & $58 \pm 6$ & $64 \pm 5$ & $62 \pm 5$ & $58 \pm 5$ & $75 \pm 4$ & $85 \pm 3$ & $59 \pm 5$ & $60 \pm 6$ \\
\hline $\mathrm{CaHPO}_{4}(\%)$ & $24 \pm 5$ & $19 \pm 4$ & $28 \pm 4$ & $32 \pm 6$ & $14 \pm 3$ & $5 \pm 2$ & $33 \pm 4$ & $35 \pm 5$ \\
\hline Ca phytate $(\%)$ & $18 \pm 4$ & $17 \pm 4$ & $10 \pm 3$ & $10 \pm 3$ & $11 \pm 3$ & $10 \pm 2$ & $8 \pm 4$ & $5 \pm 4$ \\
\hline$R$ factor & 0.012 & 0.008 & 0.007 & 0.009 & 0.005 & 0.002 & 0.009 & 0.010 \\
\hline
\end{tabular}

Table 3. Results of linear combination fitting (LCF) conducted on P $K$-edge XANES spectra of bone char (BC) and surface-modified bone char $\left(\mathrm{BC}^{\text {plus }}\right)$ particles before and after 230 days of ryegrass cultivation in a pot experiment. These best fits were achieved using all possible combinations with 19 spectra of P reference compounds.

\begin{tabular}{|c|c|c|c|c|}
\hline \multirow[t]{2}{*}{ Reference compound } & \multicolumn{2}{|c|}{ Before experiment } & \multicolumn{2}{|c|}{$\begin{array}{l}\text { After } 230 \text { days } \\
\text { ryegrass cultivation }\end{array}$} \\
\hline & $\mathrm{BC}$ & BCplus & $\mathrm{BC}$ & $B C^{\text {plus }}$ \\
\hline Ca hydroxyapatite (\%) & $63 \pm 6$ & $70 \pm 4$ & $75 \pm 4$ & $49 \pm 8$ \\
\hline $\mathrm{CaHPO}_{4}(\%)$ & $29 \pm 5$ & $29 \pm 3$ & $17 \pm 4$ & $43 \pm 6$ \\
\hline Ca phytate $(\%)$ & $8 \pm 4$ & $1 \pm 3$ & $8 \pm 3$ & $8 \pm 5$ \\
\hline$R$ factor & 0.012 & 0.005 & 0.006 & 0.018 \\
\hline
\end{tabular}


Table 4. Results of linear combination fitting (LCF) conducted on $\mathrm{P} K$-edge XANES spectra of unfertilized (control) and fertilized soils with bone char $(\mathrm{BC})$ and surface-modified bone char $\left(\mathrm{BC}^{\mathrm{plus}}\right)$ particles in the 70-day incubation-leaching experiment. These best fits were achieved using all possible combinations with 19 spectra of $\mathrm{P}$ reference compounds.

\begin{tabular}{lrrrrrr}
\hline \multirow{2}{*}{ Reference compound } & Control & \multicolumn{2}{c}{ BC treatment } & & \multicolumn{2}{c}{ BC ${ }^{\text {plus }}$ treatment } \\
\cline { 3 - 4 } & & $1-2 \mathrm{~mm}$ & $2-4 \mathrm{~mm}$ & & $1-2 \mathrm{~mm}$ & $2-4 \mathrm{~mm}$ \\
\hline Ca hydroxyapatite (\%) & $8 \pm 1$ & $4 \pm 1$ & $8 \pm 1$ & & 0 & 0 \\
$\mathrm{AlPO}_{4}$ amorphous (\%) & $42 \pm 1$ & $42 \pm 2$ & $40 \pm 1$ & & $27 \pm 1$ & $24 \pm 1$ \\
$\mathrm{FePO}_{4}(\%)$ & $29 \pm 1$ & $31 \pm 2$ & $31 \pm 1$ & & $27 \pm 1$ & $26 \pm 1$ \\
$\mathrm{SOM} \mathrm{Al}-\mathrm{AHP}(\%)$ & $21 \pm 2$ & $23 \pm 4$ & $21 \pm 3$ & & $26 \pm 2$ & $21 \pm 1$ \\
$\mathrm{Ca}\left(\mathrm{H}_{2} \mathrm{PO}_{4}\right)_{2}(\%)$ & 0 & 0 & 0 & & $20 \pm 1$ & $29 \pm 1$ \\
\hline$R$ factor & 0.0003 & 0.0007 & 0.0003 & & 0.0005 & 0.0004 \\
\hline
\end{tabular}

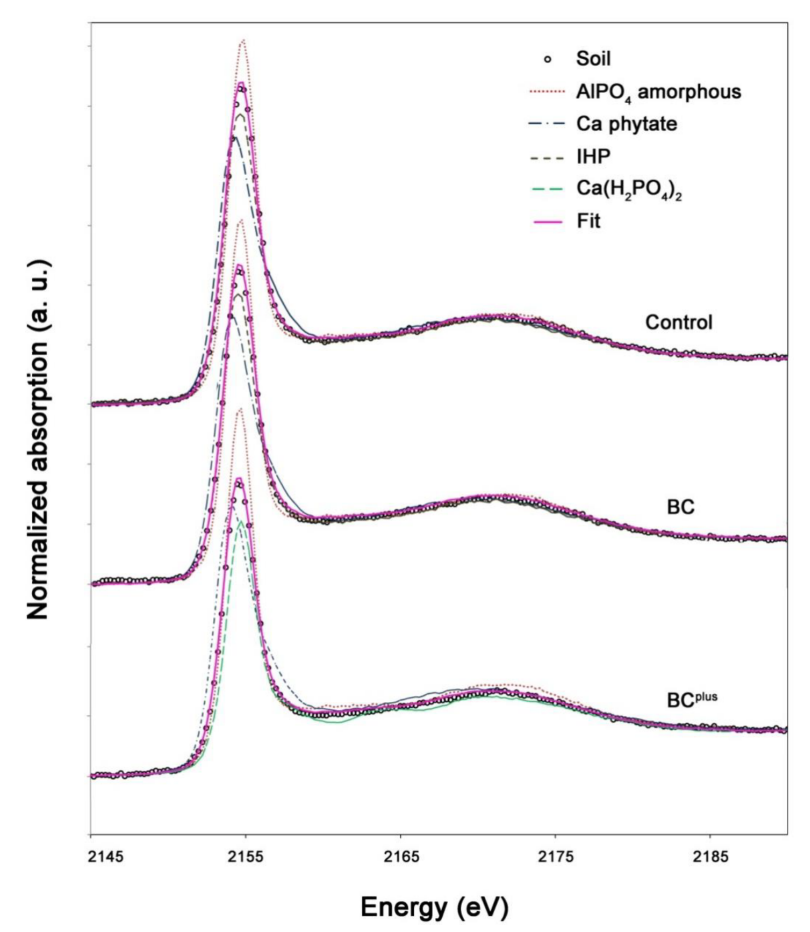

Figure 4. $\mathrm{P} K$-edge XANES spectra of unfertilized (control) and fertilized soils with $\mathrm{BC}$ and $\mathrm{BC}^{\text {plus }}$ particles under 230 days of ryegrass cultivation compared to the reference compounds selected by the LCF method.

The XANES spectra recorded from treated soil samples in the ryegrass pot experiment showed the presence of an intense white line in the energy range of 2152 to $2158 \mathrm{eV}$ and a stretched post-edge feature approximately from 2165 to $2178 \mathrm{eV}$ (Fig. 4). Decreases in white-line and post-edge intensities of the soil samples appeared as an effect of $\mathrm{BC}^{\text {plus }}$ application. Visual inspection of $\mathrm{P} K$-edge spectra revealed no indication of specific alteration in spectral features in response to the $\mathrm{BC}$ treatment.

Amorphous $\mathrm{AlPO}_{4}$ was identified by LCF analysis as the dominant component $(\approx 35 \%)$ in all treated soil samples
Table 5. Results of linear combination fitting (LCF) conducted on $\mathrm{P} K$-edge XANES spectra of unfertilized (control) and fertilized soils with bone char (BC) and surface-modified bone char (BC ${ }^{\text {plus }}$ ) particles under 230 days of ryegrass cultivation in a pot experiment. These best fits were achieved using all possible combinations with 19 spectra of $\mathrm{P}$ reference compounds.

\begin{tabular}{|c|c|c|c|}
\hline Reference compound & Control & $\mathrm{BC}$ treatment & $\mathrm{BC}^{\text {plus }}$ treatment \\
\hline $\mathrm{AlPO}_{4}$ amorphous (\%) & $35 \pm 3$ & $35 \pm 3$ & $34 \pm 1$ \\
\hline Ca phytate $(\%)$ & $27 \pm 3$ & $28 \pm 3$ & $27 \pm 1$ \\
\hline $\operatorname{IHP}(\%)$ & $29 \pm 5$ & $21 \pm 7$ & 0 \\
\hline Mont-Al-IHP (\%) & 0 & $16 \pm 1$ & 0 \\
\hline SOM-Al-IHP (\%) & 0 & 0 & $25 \pm 2$ \\
\hline Mont-Al- $-\mathrm{PO}_{4}(\%)$ & $9 \pm 1$ & 0 & 0 \\
\hline $\mathrm{Ca}\left(\mathrm{H}_{2} \mathrm{PO}_{4}\right)_{2}(\%)$ & 0 & 0 & $14 \pm 2$ \\
\hline$R$ factor & 0.0006 & 0.0008 & 0.0006 \\
\hline
\end{tabular}

from the ryegrass pot experiment (Table 5). The second major P form in the control soil was IHP (29\%), followed by Ca phytate $(27 \%)$, with the latter also as pronounced as that observed for $\mathrm{BC}$ and $\mathrm{BC}^{\text {plus }}$ treatments. All treated soils varied in proportions of free or bound IHP forms. The Mont-Al$\mathrm{PO}_{4}$ and $\mathrm{Ca}\left(\mathrm{H}_{2} \mathrm{PO}_{4}\right)_{2}$ compounds were only assigned in the control and $\mathrm{BC}^{\text {plus }}$ treatments, respectively.

\section{Discussion}

\subsection{P availability as revealed by sequential fractionation}

The sequence of $\mathrm{P}$ distribution between sequentially extracted $\mathrm{P}$ fractions was in accordance with findings by many studies (Cross and Schlesinger, 1995; McDowell and Stewart, 2006; Hashimoto and Watanabe, 2014), reflecting the general status of different $\mathrm{P}$ pools in acidic soils. The results indicated that the largest $\mathrm{P}$ proportion was found in the $\mathrm{NaOH}$ fraction, reflecting $\mathrm{P}$ fixed to $\mathrm{Fe}$ and $\mathrm{Al}$ oxides, followed by the $\mathrm{NaHCO}_{3}-\mathrm{P}$ fraction assigned to $\mathrm{P}$ weakly absorbed on crystalline $\mathrm{Fe}$ and $\mathrm{Al}$ oxides or surface of minerals. Guo et al. (2000) reported that the $\mathrm{NaOH}-\mathrm{P}$ fraction may support the labile $\mathrm{NaHCO}_{3}-\mathrm{P}$ fraction as a buffering $\mathrm{P}$ 
pool in highly weathered and acidic soils. According to soil $\mathrm{pH}$ values (4.7 and 5.2), the larger proportions of $\mathrm{NaHCO}_{3}-$ $\mathrm{P}$ even than $\mathrm{HCl}-\mathrm{P}$ can be explained by the abundance and surface loadings of $\mathrm{Fe}$ and $\mathrm{Al}$ oxides that support the electrostatic binding of phosphate ions and a scarcity of $\mathrm{Ca}$ and $\mathrm{Mg}$ minerals or soluble ions. As expected, the lowest $\mathrm{P}$ proportions were found in the mobile and readily available $\mathrm{P}$ fraction extracted by resin strips in agreement with many comparable studies (Cross and Schlesinger, 1995; Bauchemin et al., 2003; Sharpley et al., 2004; Siebers et al., 2013). Among the two soils that were used in the two different experiments, the largest proportions of inorganic $\mathrm{P}$ were achieved in the soil after the incubation-leaching experiment, while the organic $\mathrm{P}$ forms were considerably more abundant in the soil samples after ryegrass cultivation (Table 1 ). These differences may be due to the microbial activities in the rhizosphere of grasses and the transformation of $\mathrm{P}_{\mathrm{i}}$ to more stable $\mathrm{P}_{\mathrm{o}}$ fractions during the longer plant cultivation period ( 230 days) than in the non-cropped incubation-leaching experiment (70 days).

In general, all P-fraction concentrations were elevated by adding $\mathrm{BC}$ and $\mathrm{BC}^{\text {plus }}$ particles, which appeared to follow the same pattern in both soils under two different experimental conditions. However, significant differences were found only between the control and $\mathrm{BC}^{\text {plus }}$-treated soils (1-2 mm in the incubation-leaching experiment) for the resin- $\mathrm{P}$ and $\mathrm{NaOH}-\mathrm{P}$ fractions. Since the $\mathrm{BC}-\mathrm{BC}{ }^{\text {plus }}$ particles were separated from the soils before chemical analysis, it was expected that partly dissolved BCs would have a limited impact on different $P$ fractions rather than totally ground and mixed BCs. This is consistent with the study of Siebers et al. (2013) according to which the BC application $(<90 \mu \mathrm{m}$ BC thoroughly mixed in soil) significantly increased the insoluble $\mathrm{P}$ proportion $\left(\mathrm{H}_{2} \mathrm{SO}_{4}-\mathrm{P}\right)$. Additionally, our study confirmed previous findings concerning the effect of particle sizes on the P release from BCs (Morshedizad and Leinweber, 2017) and consequently the P status of treated soils (Ma and Matsunaka, 2013). Sequentially extracted $P$ contents increased with the decreasing size of $\mathrm{BC}$ particles whereby $\mathrm{BC}^{\text {plus }}$ treatments appeared more dependent on particle size than $\mathrm{BC}$ treatments. The results of the sequential $\mathrm{P}$ fractionation of $\mathrm{BC}^{\text {plus }}$ treatments in the incubation-leaching experiment indicated that the $\mathrm{P}$ increase was more pronounced for $\mathrm{P}$ fixed to $\mathrm{Al}$ and $\mathrm{Fe}$ oxides $(\mathrm{NaOH}-\mathrm{P})$ than other fractions, whereas for $\mathrm{BC}$ treatments the largest increase occurred in $\mathrm{P}$ bound to $\mathrm{Ca}$ and $\mathrm{Mg}$ minerals ( $\mathrm{HCl}-\mathrm{P})$. It seems that local $\mathrm{pH}$ changes in soil associated with $\mathrm{BC}$ and $\mathrm{BC}^{\text {plus }}$ amendments could eventually lead to a different distribution of released $\mathrm{P}$ into different soluble or insoluble $\mathrm{P}$ pools, which are generally controlled by $\mathrm{pH}$ (Arai and Sparks, 2007). However, due to a lower fertilization level and a longer period of experiment in ryegrass cultivation compared to incubation leaching, it appears that the chemical equilibrium has been established in the soil (no significant change in bulk soil $\mathrm{pH}$ ), and accordingly the soil $\mathrm{P}$ fractions were altered minimally.

\subsection{P speciation of BC-BC ${ }^{\text {plus }}$ particles by XANES}

The predominance of Ca hydroxyapatite in BCs as evidenced by $\mathrm{P} K$-edge XANES analysis is consistent with findings reported by previous studies (Warren et al., 2009; Siebers et al., 2013). The mineral phase of bone consists mainly of hydroxyapatite, and its contribution to bone and bone char compositions depends on species, the age of animals (Wu et al., 2003), carbonization temperature and residence time (Novotny et al., 2012). Bone crystallinity might be improved through structural modifications on poorly crystalline fresh bone samples (such as mineral maturity over periods of time or intensive carbonization), which can also result in increased proportions of hydroxyapatite and accordingly a decrease in P solubility (Novotny et al., 2012). Based on $\mathrm{LC}$ fittings, the second major component of $\mathrm{BC}-\mathrm{BC}^{\text {plus }}$ particles was $\mathrm{CaHPO}_{4}$, in good agreement with the results of Rajendran et al. (2013) who indicated that heated bones at $400{ }^{\circ} \mathrm{C}$ contained some more soluble phosphates, such as $\mathrm{CaHPO}_{4}$ and $\mathrm{CaH}_{2} \mathrm{PO}_{4}$, in addition to the hydroxyapatite fraction. The authors reported that spectra of calcined bone samples at $700^{\circ} \mathrm{C}$ had a white line at $2154 \mathrm{eV}$ and two postedge peaks at $2162 \mathrm{eV}$ and $2169 \mathrm{eV}$, with no pre-edge peaks, and appeared similar to $\mathrm{CaHPO}_{4}$ and $\mathrm{CaH}_{2} \mathrm{PO}_{4}$ spectra. Our $\mathrm{LCF}$ also assigned $\mathrm{Ca}$ phytate in $\mathrm{BC}-\mathrm{BC}^{\text {plus }}$ samples, which seems to be controversial as a component of animal bone materials. The $\mathrm{P} K$-edge spectrum of Ca phytate is very similar to other Ca-bound $\mathrm{P}$ compounds with a distinct white line and lack of a pre-edge feature, although it is likely distinguishable due to the specific shape of white-line tailing and the absence of a post-edge signal at $2164 \mathrm{eV}$ (Prietzel et al., 2016). Moreover, some inaccuracies in LCF estimations have to be considered because of (1) uncertainty in the speciation of organic $\mathrm{P}$ forms by $K$-edge XANES, (2) lack of reference compounds representing all $\mathrm{P}$ forms in BCs and (3) smaller Ca phytate proportions than the proposed 10 to $15 \%$ of $\mathrm{P}_{\mathrm{t}}$ as a detection limit for reliable XANES fittings (Beauchemin et al., 2003). Therefore, the P proportions assigned to Ca phytate could also originate from a range of other $\mathrm{Ca}-\mathrm{P}$ compounds.

In both experiments, incubation leaching and ryegrass cropping, changes in the proportions of $\mathrm{Ca}$ hydroxyapatite and $\mathrm{CaHPO}_{4}$ in $\mathrm{BC}$ particles followed an opposite trend than in $\mathrm{BC}^{\text {plus }}$ particles. After the placement of $\mathrm{BC}$ particles in the soil, Ca phosphate seemed to be released gradually over time, which provides a locally lime-saturated condition. Due to elevated $\mathrm{pH}$ surrounding the $\mathrm{BC}$ particles, dissolved $\mathrm{P}$ can be resorbed to maintain solubility and the $\mathrm{Ca}-\mathrm{P}$ equilibrium constant, which likely resulted in a decreased proportion of soluble $\mathrm{CaHPO}_{4}$ and possibly transformation into the relatively insoluble $\mathrm{Ca}$ hydroxyapatite fraction. In contrast, if $\mathrm{BC}^{\text {plus }}$ particles were applied to soils, larger proportions of $\mathrm{CaHPO}_{4}$ at the expense of Ca hydroxyapatite could be explained by soil acidification through the microbial oxidation of released S (Lee, et al. 1987; Fan et al., 2002). This effect 
was more pronounced over the longer time period in the ryegrass cropping pot experiment, favoring a greater $\mathrm{CaHPO}_{4}$ than $\mathrm{Ca}$ hydroxyapatite fraction. This implies that $\mathrm{BC}^{\text {plus }}$ can actively supply $\mathrm{P}$ with a predominance of soluble over insoluble $\mathrm{P}$ forms in the long term and thus meet crop requirements.

\subsection{P speciation of treated soils by XANES}

Differences between the characteristics of the two soils, dissimilar mechanisms of incubation leaching and plant uptake, and different experiment time durations complicate the joint interpretation of the P XANES data. In the unfertilized soil of the incubation-leaching experiment, the proportions of $\mathrm{P}$ species followed the order $\mathrm{AlPO}_{4}>\mathrm{FePO}_{4}>\mathrm{SOM}-\mathrm{Al}-$ IHP $>\mathrm{Ca}$ hydroxyapatite, which did not vary despite partial changes in some proportions after the application of both size fractions of BC particles. In general, these results concur with the findings by Siebers et al. (2013) that Ca hydroxyapatite proportion was slightly increased by BC application. This could be attributed to irreversibly mixing finely ground $\mathrm{BC}$ in the soil samples, whereas in the present experiments the $\mathrm{BC}$ particles were separated from the soils before $\mathrm{P}$ speciation. Furthermore, these XANES data (Table 4 and Table 5) are in agreement with sequential P-fractionation results (Table 1), which indicated the dominance of inorganic over organic $\mathrm{P}$ forms and showed the $\mathrm{P}$ fractions almost unchanged after BC application. Implications of the low solubility of $\mathrm{BC}$ particles observed in this work are consistent with previous studies showing a slow release of $\mathrm{P}$ from BCs (Warren et al., 2009; Siebers et al., 2013; Morshedizad et al., 2016). Besides reducing the $\mathrm{AlPO}_{4}$ and $\mathrm{Ca}$ hydroxyapatite proportions, $\mathrm{BC}^{\text {plus }}$ particles introduced highly soluble $\mathrm{Ca}\left(\mathrm{H}_{2} \mathrm{PO}_{4}\right)_{2}$ to soils in the incubation-leaching experiment. These results imply that considerable changes in $\mathrm{P}$ speciation were more attributed to $\mathrm{pH}$ reductions, and accordingly leaching losses of solubilized $\mathrm{P}$ forms compared with $\mathrm{P}$ enrichment by $\mathrm{BC}^{\text {plus }}$ dissolution. This is supported by results from a previous publication in which two particle sizes of $\mathrm{BC}^{\text {plus }}$ gave a significant rise in the leached $\mathrm{P}$ concentration after 1, 5, 13, 34 and 70 days of incubation along with reductions in soil pH (Morshedizad and Leinweber, 2017). This is in line with Sato et al. (2005) who found that increasing soil $\mathrm{pH}$ in a naturally acidic soil $(\mathrm{pH}=4.32)$ was an effective approach to minimize $\mathrm{P}$ leaching, while $\mathrm{pH}$ decrease resulted in the transformation of stable to soluble and more leachable P species. Regarding the XANES results of the ryegrass cultivation experiment (Table 5), the effect of $\mathrm{BC}^{\text {plus }}$ treatment can be better explained. In the control soil, the presence of $\mathrm{AlPO}_{4}$ and the increasing abundance of organic $\mathrm{P}$ forms (Ca phytate and IHP compounds; Table 5) were consistent with the appearance of $\mathrm{NaOH}-\mathrm{P}$ and $\mathrm{HCl}-\mathrm{P}$ fractions by sequential extraction (Table 1). In the $\mathrm{BC}$ treatment the proportions of $\mathrm{AlPO}_{4}$ and $\mathrm{Ca}$ phytate did not change compared to the control, but the contribution of organic $\mathrm{P}$ in- creased by Mont-Al-IHP formation. The stability of different $\mathrm{P}$ fractions can be favored by the $\mathrm{pH}$ effect (Gustafsson et al., 2012) and likewise the dependence of BC particle solubility on the soil $\mathrm{pH}$ (Siebers et al., 2013). In agreement with the incubation-leaching results (Table 4), $\mathrm{Ca}\left(\mathrm{H}_{2} \mathrm{PO}_{4}\right)_{2}$ was detected as a result of $\mathrm{BC}^{\text {plus }}$ amendment even though similar proportions of $\mathrm{AlPO}_{4}$ and $\mathrm{Ca}$ phytate were observed between the control and the $\mathrm{BC}^{\text {plus }}$ treatment. However, the data in Table 5 on the presence or absence of $\mathrm{Ca}\left(\mathrm{H}_{2} \mathrm{PO}_{4}\right)_{2}$ in soils of ryegrass experiment may have been influenced by small proportions ( $<10-15 \%$; reliable detection limit by XANES; Beauchemin et al., 2003) of other simple calcium phosphates that have a spectrum similar to the one of $\mathrm{Ca}\left(\mathrm{H}_{2} \mathrm{PO}_{4}\right)_{2}$ in the LCF analysis. The results of sequential $\mathrm{P}$ fractionation and XANES analyses on treatments in the two different experiments presented here demonstrated that the surface modification of BC particles effectively improved soluble $\mathrm{P}$ fractions in $\mathrm{BC}^{\text {plus }}$ particles and consequently in amended soils.

\section{Conclusions}

In the present study, $\mathrm{P}$ speciation by sequential $\mathrm{P}$ fractionation and $\mathrm{P} K$-edge XANES spectroscopy revealed the noticeable alteration in the $\mathrm{P}$ pools of treated soil samples. The results of incubation-leaching and ryegrass cultivation experiments indicated that $\mathrm{BC}^{\text {plus }}$ produced by the surface modification of $\mathrm{BC}$ through the addition of $\mathrm{S}$ compounds provided more soluble and plant-available $\mathrm{P}$ than non-modified $\mathrm{BC}$ during the growth season. The $\mathrm{S}$ oxidation and thereby the soil $\mathrm{pH}$ decrease seems to stimulate the $\mathrm{P}$ release from $\mathrm{BC}^{\text {plus }}$ particles. The $\mathrm{P} K$-edge XANES analyses of $\mathrm{BC}^{\text {plus }}$ particles revealed more soluble $\mathrm{CaHPO}_{4}$ than in BC particles at the expense of $\mathrm{Ca}$ hydroxyapatite. This was associated with the addition $\mathrm{Ca}\left(\mathrm{H}_{2} \mathrm{PO}_{4}\right)_{2}$ or similar simple $\mathrm{Ca}-\mathrm{P}$ compounds to amended soils, as indicated by sequential $\mathrm{P}$ fractionation and XANES analyses. Future studies will be directed to validate the beneficial effects of $\mathrm{BC}^{\text {plus }}$ on the field scale with different soils and to optimize the surface modification of BCs.

Data availability. All compiled data in this study are published in figures and tables. Detailed primary data, including the acquired XANES spectra, are saved and published in the BonaRes Data Centre and available at: https://doi.org/10.20387/BonaRes-PDY6HHGS (Morshedizad and Leinweber, 2017).

Competing interests. The authors declare that they have no conflict of interest.

Acknowledgements. We are grateful to the technician team and all staff at the beamline 8 of SLRI for their help and assistance associated with XANES spectra acquisitions. The authors are appreciative of Jörg Prietzel (Department of Soil Science, Tech- 
nical University of Munich) for providing the P reference spectra and invaluable comments that improved our research. Mohsen Morshedizad acknowledges a PhD grant from the Federal State of Mecklenburg, Western Pomerania in Germany and travel expenses from the Leibniz ScienceCampus Phosphorus Research Rostock. Parts of this work were funded by the German Federal Ministry of Education and Research (BMBF) through the BonaRes project InnoSoilPhos (no. 031A558).

Edited by: Claudio Zaccone

Reviewed by: Sander Bruun and one anonymous referee

\section{References}

Ahlgren, J., Djodjic, F., Börjesson, G., and Mattsson, L.: Identification and quantification of organic phosphorus forms in soils from fertility experiments, Soil Use Manag., 29, 24-35, https://doi.org/10.1111/sum.12014, 2013.

Arai, Y. and Sparks, D. L.: Phosphate reaction dynamics in soil and soil components: a multiscale approach, Adv. Agron., 94, 135179, https://doi.org/10.1016/S0065-2113(06)94003-6, 2007.

Beauchemin, S., Hesterberg, D., Chou, J., Beauchemin, M., Simard, R. R., and Sayers, D.E.: Speciation of phosphorus in phosphorusenriched agricultural soils using X-ray absorption near-edge structure spectroscopy and chemical fractionation, J. Environ. Qual., 32, 1809-1819, https://doi.org/10.2134/jeq2003.1809, 2003.

Condron, L. M. and Newman, S.: Revisiting the fundamentals of phosphorus fractionation of sediments and soils, J. Soil Sediment, 11, 830-840, https://doi.org/10.1007/s11368-011-0363-2, 2011.

Cross, A. F. and Schlesinger, W. H.: A literature-review and evaluation of the Hedley fractionation - applications to the biochemical cycle of soil-phosphorus in natural ecosystems, Geoderma, 64, 197-214, https://doi.org/10.1016/0016-7061(94)00023-4, 1995.

De Brabandere, H., Forsgard, N., Israelsson, L., Petterson, J., Rydin, E., Waldebäk, M., and Sjöerg, P. J.: Screening for organic phosphorus compounds in aquatic sediments by liquid chromatography coupled to ICP-AES and ESI-MS/MS, Anal. Chem., 80, 6689-6697, https://doi.org/10.1021/ac8006335, 2008.

Delgado, A., Madrid, A., Kassem, S., Andreu, L., and Campillo, M. C.: Phosphorus fertilizer recovery from calcareous soils amended with humic and fulvic acids, Plant Soil, 245, 277-286, https://doi.org/10.1023/A:1020445710584, 2002.

Dieter, D., Elsenbeer, H., and Turner, B. L.: Phosphorus fractionation in lowland tropical rainforest soils in central Panama, Catena, 82, 118-125, https://doi.org/10.1016/j.catena.2010.05.010, 2010.

Fan, X., Habib, L., Fleckenstein, J., Haneklaus, S., and Schnug, E.: "In situ digestion" a concept to manage soil phosphate in organic farming, in: Proc. of the 13th Intern. Fertilizer Symposium, Tokat, Turkey, 10-13 June 2002. 219-228, 2002.

Fan, X., Schnug, E., Haneklaus, S., and Li, Y.: In situ digestion of rock phosphates to mobilize plant-available phosphate for organic farming, Commun. Soil Sci. Plant, 43, 2191-2201, https://doi.org/10.1080/00103624.2012.708073, 2012.

Guo, F., Yost, R. S., Hue, N. V., Evensen, C. I., and Silva, J. A.: Changes in phosphorus fractions in soils under in- tensive plant growth, Soil Sci. Soc. Am. J., 64, 1681-1689, https://doi.org/10.2136/sssaj2000.6451681x, 2000.

Gustafsson, J. P., Mwamila, L. B., and Kergoat, K.: The $\mathrm{pH}$ dependence of phosphate sorption and desorption in Swedish agricultural soils, Geoderma, 189-190, 304-311, https://doi.org/10.1016/j.geoderma.2012.05.014, 2012.

Hartley, T. N., Macdonald, A. J., McGrath, S. P., and Zhao, F. J.: Historical arsenic contamination of soil due to long-term phosphate fertiliser applications, Environ. Pollut., 180, 259-264, https://doi.org/10.1016/j.envpol.2013.05.034, 2013.

Hashimoto, Y. and Watanabe, Y.: Combined applications of chemical fractionation, solution 31P-NMR and $\mathrm{P} \mathrm{K}$ edge XANES to determine phosphorus speciation in soils formed on serpentine landscapes, Geoderma, 230, 143-150, https://doi.org/10.1016/j.geoderma.2014.04.001, 2014.

He, Q. B. and Singh, B. R.: Plant availability of cadmium in soils: I. Extractable cadmium in newly and long-term cultivated soils, Acta. Agric. Scand. Sect. B, 43, 134-141, https://doi.org/10.1080/09064719309411231, 1993.

Hedley, M. J., Stewart, J. W. B., and Chauhan, B. S.: Changes in organic and organic soil phosphorus fractions induced by cultivation practices and laboratory incubations, Soil Sci. Soc. Am. J., 46, 970-976, https://doi.org/10.2136/sssaj1982.03615995004600050017x, 1982.

Herzel, H., Krüger, O., Hermann, L., and Adam, C.: Sewage sludge ash - A promising secondary phosphorus source for fertilizer production, Sci. Total Environ., 542, 1136-1143, https://doi.org/10.1016/j.scitotenv.2015.08.059, 2016.

Kaur, G. and Reddy, M. S.: Role of phosphate-solubilizing bacteria in improving the soil fertility and crop productivity in organic farming, Arch. Agron. Soil Sci., 60, 549-564, https://doi.org/10.1080/03650340.2013.817667, 2014.

Kelly, S., Hesterberg, D., and Ravel, B.: Analysis of soils and minerals using x-ray absorption spectroscopy, in: Methods of soil analysis. Part 5. Mineralogical methods, edited by: Ulery, A. L. and Drees, R., SSSA, Madison, WI., 387-463, 2008.

Kizewski, F., Liu, Y. T., Morris, A., and Hesterberg, D.: Spectroscopic approaches for phosphorus speciation in soils and other environmental systems, J. Environ. Qual., 40, 751-766, https://doi.org/10.2134/jeq2010.0169, 2011.

Klysubun, W., Sombunchoo, P., Deenan, W., and Kongmark, C.: Performance and status of beamline BL8 at SLRI for X-ray absorption spectroscopy, J. Synchrotron Rad., 19, 930-936, https://doi.org/10.1107/S0909049512040381, 2012.

Kratz, S., Schick, J., and Schnug, E.: Trace elements in rock phosphates and $\mathrm{P}$ containing mineral and organo-mineral fertilizers sold in Germany, Sci. Total Environ., 542, 1013-1019, https://doi.org/10.1016/j.scitotenv.2015.08.046, 2016.

Kruse, J., Abraham, M., Amelung, W., Baum, C., Bol, R., Kuhn, O., Lewandowski, H., Niederberger, J., Oelmann, Y., Ruger, C., Santner, J., Siebers, M., Siebers, N., Spohn, M., Vestergren, J., Vogts, A., and Leinweber, P.: Innovative methods in soil phosphorus research: a review, J. Plant Nutr. Soil Sci., 178, 43-88, https://doi.org/10.1002/jpln.201400327, 2015.

Lanfranco, A. M., Schofield, P. F., Murphy, P. J., Hodson, M. E., Mosselmans, J. F. W., and Valsami-Jones, E.: Characterization and identification of mixed-metal phosphates in soils: the appli- 
cation of Raman spectroscopy, Mineral. Mag., 67, 1299-1316, https://doi.org/10.1180/0026461036760166, 2003.

Lee, A., Watkinson, J. H., Orbell, G., Bagyaraj, J., and Lauren, D. R.: Factors influencing dissolution of phosphate rock and oxidation of elemental sulphur in some New Zealand soils, New Zeal. J. Agr. Res., 30, 373-385, https://doi.org/10.1080/00288233.1987.10421898, 1987.

Liu, J. Y., Wang, H., Yang, H. J., Ma, Y. J., and Cai, O. C.: Detection of phosphorus species in sediments of artificial landscape lakes in China by fractionation and phosphorus-31 nuclear magnetic resonance spectroscopy, Environ. Pollut., 157, 49-56, https://doi.org/10.1016/j.envpol.2008.07.031, 2009.

Ma, Y. L. and Matsunaka, T.: Biochar derived from dairy cattle carcasses as an alternative source of phosphorus and amendment for soil acidity, Soil Sci. Plant Nutr., 59, 628-641, https://doi.org/10.1080/00380768.2013.806205, 2013.

McDowell, R. W. and Stewart, I.: The phosphorus composition of contrasting soils in pastoral, native and forest management in Otago, New Zealand: Sequential extraction and ${ }^{31} \mathrm{P}$ NMR, Geoderma, 130, 176-189, https://doi.org/10.1016/j.geoderma.2005.01.020, 2006.

Morshedizad, M. and Leinweber, P.: Leaching of phosphorus and cadmium in soils amended with different bone chars, CLEAN-Soil Air Water, 45, 1600635, https://doi.org/10.1002/clen.201600635, 2017.

Morshedizad, M. and Leinweber, P.: Raw_XANES_Data_vervollständigt (Rohdaten XANES Messungen), BonaRes Data Centre, Leibniz Centre for Agricultural Landscape Research (ZALF), https://doi.org/10.20387/BonaRes-PDY6-HHGS, 2017.

Morshedizad, M., Zimmer, D., and Leinweber, P.: Effect of bone chars on phosphorus-cadmium-interactions as evaluated by three extraction procedures, J. Plant Nutr. Soil Sci., 179, 388-398, https://doi.org/10.1002/jpln.201500604, 2016.

Murphy, J. and Riley, J. P.: A modified single solution method for the determination of phosphate in natural waters, Anal. Chim. Acta, 27, 31-36, https://doi.org/10.1016/S0003-2670(00)88444$5,1962$.

Novotny, E. H., Auccaise, R., Velloso, M. H. R., Corrêa, J. C., Higarashi, M. M., Abreu, V. M. N., Rocha, J. D., and Kwapinski, W.: Characterization of phosphate structures in biochar from swine bones, Pesq. Agropec. Bras., 47, 672-676, https://doi.org/10.1590/S0100-204X2012000500006, 2012.

Paraskova, J. V., Jorgensen, C., Reitzel, K. Pettersson, J., Rydin, E., and Sjoberg, P. J. R.: Speciation of inositol phosphates in lake sediments by ion-exchange chromatography coupled with mass spectrometry, inductively coupled plasma atomic emission spectroscopy, and ${ }^{31} \mathrm{P}$ NMR spectroscopy, Anal. Chem., 87, 26722677, https://doi.org/10.1021/ac5033484, 2015.

Powers, W. L.: Sulfur in relation to soil fertility, Station Bulletin 199 of the Oregon Agricultural College Experiment Station, available at: http://ir.library.oregonstate.edu/xmlui/bitstream/handle/1957/ 14537/StationBulletin199.pdf?sequence=1 (last access: 4 Oktober 2017), 45 pp., 1923.

Prietzel, J., Dümig, A., Wu, Y., Zhou, J., and Klysubun, W.: Synchrotron-based P K-edge XANES spectroscopy reveals rapid changes of phosphorus speciation in the topsoil of two glacier foreland chronosequences, Geochim. Cosmochim. Ac., 108, 154-171, https://doi.org/10.1016/j.gca.2013.01.029, 2013.
Prietzel, J., Harrington, G., Häusler, W., Heister, K., Werner, F., and Klysubun, W.: Reference spectra of important adsorbed organic and inorganic phosphate binding forms for soil $\mathrm{P}$ speciation using synchrotron-based $K$-edge XANES spectroscopy, J. Synchrotron Rad., 23, 532-544, https://doi.org/10.1107/S1600577515023085, 2016.

Rajendran, J., Gialanella, S., and Aswath, P. B.: XANES analysis of dried and calcined bones, Mater. Sci. Eng. C, 33, 3968-3979, https://doi.org/10.1016/j.msec.2013.05.038, 2013.

Ravel, B. and Newville, M.: Athena, Artemis, Hephaestus: data analysis for X-ray absorption spectroscopy using IFEFFIT, J. Synchrotron Rad., 12, 537-541, https://doi.org/10.1107/S0909049505012719, 2005.

Rubaek, G. H., Kristensen, K., Olesen, S. E., Ostergaard, H. S., and Heckrath, G.: Phosphorus accumulation and spatial distribution in agricultural soils in Denmark, Geoderma, 209, 241-250, https://doi.org/10.1016/j.geoderma.2013.06.022, 2013.

Sato, S., Solomon, D., Hyland, C., Ketterings, Q. M., and Lehmann, J.: Phosphorus speciation in manure and manure-amended soils using XANES spectroscopy, Environ. Sci. Technol., 39, 74857491, https://doi.org/10.1021/es0503130, 2005.

Schnug, E., Haneklaus, S., Rogasik, J., and Gassner, A.: Utilisation of fertiliser $\mathrm{P}$ with special regard to organic farming, in: Proc. of the 14th Intern. Symposium of Fertilizers, Debrecen, Hungary, 22-25 June 2003, 11-29, 2003.

Scholz, R. W., Ulrich, A. E., Eilittä, M., and Roy, A.: Sustainable use of phosphorus: a finite resource, Sci. Total Environ., 461462, 799-803, https://doi.org/10.1016/j.scitotenv.2013.05.043, 2013.

Schröder, J. J., Smit, A. L., Cordell, D., and Rosemarin, A.: Improved phosphorus use efficiency in agriculture: a key requirement for its sustainable use, Chemosphere, 84, 822-831, https://doi.org/10.1016/j.chemosphere.2011.01.065, 2011.

Sharpley, A. N., McDowell, R. W., and Kleinman, P. J. A.: Amounts, forms and solubility of phosphorus in soils receiving manure, Soil Sci. Soc. Am. J., 68, 2048-2054, https://doi.org/10.2136/sssaj2004.2048, 2004.

Shen, J. B., Yuan L. X., Zhang J. L., Li H. G., Bai Z. H., Chen, X. P., Zhang, W. F., and Zhang, F. S.: Phosphorus dynamics: from soil to plant, Plant Physiol., 156, 997-1005, https://doi.org/10.1104/pp.111.175232, 2011.

Siebers, N. and Leinweber, P.: Bone Char - A clean and renewable fertilizer with cadmium immobilizing capacity, J. Environ. Qual., 42, 405-411, https://doi.org/10.2134/jeq2012.0363, 2013.

Siebers, N., Kruse, J., and Leinweber, P.: Speciation of phosphorus and cadmium in a contaminated soil amended with bone char: sequential fractionations and XANES spectroscopy, Water Air Soil Pollut., 224, 1564-1577, https://doi.org/10.1007/s11270013-1564-7, 2013.

Templeton, D. M., Ariese, F., Cornelis, R., Danielsson, L. G., Muntau, H., Van Leewen, H. P., and Lobinski, R.: Guidelines for the terms related to chemical speciation and fractionation of elements. Definitions, structural aspects, and methodological approaches (IUPAC Recommendations 2000), Pure Appl. Chem., 72, 1453-1470, https://doi.org/10.1351/pac200072081453, 2000.

Toor, G. S., Hunger, S., Peak, J. D., Sims, J. T., and Sparks, D. L.: Advances in the characterization of phosphorus in organic wastes: Environmental and agronomic applications, Adv. 
Agron.,89, 1-72, https://doi.org/10.1016/S0065-2113(05)890017, 2006.

USEPA: Method 305la: Microwave assisted acid dissolution of sediments, sludges, soils, and oils, 2nd ed., U.S. Gov. Print. Office, Washington, DC, 1997.

Van Vuuren, D. P., Bouwman, A. F., and Beusen, A. H. W.: Phosphorus demand for the 1970-2100 period: A scenario analysis of resource depletion, Global Environ. Change, 20, 428-439, https://doi.org/10.1016/j.gloenvcha.2010.04.004, 2010.

Vestergren, J., Vincent, A. G., Jansson, M., Persson, P., Ilstedt, I., Gröbner, G., Giesler, R., and Schleucher, J.: High-resolution characterization of organic phosphorus in soil extracts using 2D ${ }^{1} \mathrm{H}-\mathrm{P}^{31} \mathrm{NMR}$ correlation spectroscopy, Environ. Sci. Technol., 46, 3950-3956, https://doi.org/10.1021/es204016h, 2012.

Vogel, C., Adam, C., Sekine, R., Schiller, T., Lipiec, E., and McNaughton, D.: Determination of phosphorus fertilizer soil reactions by Raman and synchrotron infrared microspectroscopy, Appl. Spectrosc.,67, 1165-1170, https://doi.org/10.1366/1307056, 2013.
Warren, G. P., Robinson, J. S., and Someus, E.: Dissolution of phosphorus from animal bone char in 12 soils, Nutr. Cycling Agroecosyst., 84, 167-178, https://doi.org/10.1007/s10705-008-92356, 2009.

Werner, F. and Prietzel, J.: Standard protocol and quality assessment of soil phosphorus speciation by $\mathrm{P} K$-edge XANES spectroscopy, Environ. Sci. Technol., 49, 10521-10528, https://doi.org/10.1021/acs.est.5b03096, 2015.

Wu, Y., Ackerman, J. L., Strawich, E. S, Rey, C., Kim, H-M., and Glimcher, M. J.: Phosphate ions in bone: identification of a calcium-organic phosphate complex by ${ }^{31} \mathrm{P}$ solid-state NMR spectroscopy at early stages of mineralization, Calcif. Tissue Int., 72, 610-26, https://doi.org/10.1007/s00223-002-1068-8, 2003. 